\title{
Impact of Oil Price Fluctuations on Omani Narrow Money Supply (M1) - (1980-2016)
}

\author{
Dr. Bilal Khlaf Al.Omari ${ }^{*}$, Mr. Abubakar El-Sidig Ali Ahmed ${ }^{2}$ \\ ${ }^{1}$ Assistant Professor in Economics, Business Administration and Accounting Department, Al Buraimi University College, \\ Al Buraimi Sultanate of Oman; bilal@buc.edu.om
}

${ }^{2}$ Economics Lecturer, Business Administration and Accounting Department, Al Buraimi University College, Al Buraimi, Sultanate of Oman; abubaker@buc.edu.om

Corresponding Author: Dr. Bilal Khlaf Al.Omari; bilal@buc.edu.om

Received 11 October 2019; $\quad$ Accepted 20 October 2019;

Published 31 October 2019

\begin{abstract}
The Omani economy frequently moves in unison with changing oil prices because it is highly dependent on this commodity. Given this relationship, it is reasonable to theorize that the Omani narrow money supply (M1) is also sensitive to oil price fluctuations. This study examines the linkages between oil price changes and the M1 money supply in Oman for the period 1980 to 2016 and analyzes the nature of discovered relationships. An autoregressive distributed lag model is used to test the relationship between Omani oil price fluctuations and the money supply over time from 37 annual observations. This study finds that changes in oil prices and the M1 money supply are strongly correlated in the long run, which has implications for policymakers looking to diversify the Omani economy.
\end{abstract}

Keywords: Oil price fluctuations, narrow money supply (M1), autoregressive distributed lag (ARDL), time series econometrics, and Oman economic diversity.

\section{Introduction}

The Sultanate of Omanis an emerging economy, relying exclusively on oil revenues (Al-Mawali and Al-Busaidi, 2016; Alodayni, 2016). Crude oil accounts for 59\% of aggregate export earnings and $84.7 \%$ of government proceeds; thus, the Omani economy, like other Gulf Cooperation Council (GCC) member nations, is especially sensitive to oscillations in global crude oil prices (Ahmed, 2018a). This study seeks to understand if a similar relationship exists between oil prices and the Omani money supply - defined as the narrow money supply or M1.

\subsection{Oman and the Narrow Money Supply}

Under the Keynesian framework, the M1 money supply is comprised of currency in circulation and demand deposits held in commercial banks. The Sultanate'sM1money supply increased slowly until 1970 but exhibited uneven increases afterward.M1growthresulted from the expansion of oil exports, with the share of the country's currency exceeding $50 \%$ of its M1money supply from 1973 to2000. The currency percentage started to declinein2001 with the more widespread use of demand deposits.

Econometric analyses have shown specific links between the money supply and variables such as GDP, deficits, global reserves and oil exports. Analyses of financial indicators have revealed that private sector net national credit and banking system net foreign assets are the major components that positively influence the money supply. Conversely, the quasi money used for time deposits, savings deposits, capital accounts, and reserve accounts were shown to have a deficit effect on the money supply from 1974 to 2003 (Ahmad, 2019a).

Omani M1 averaged OMR. 2411.08M from 1999 through2018, obtaining an all-time high of OMR 5480.30Mduring 2015 and low of OMR 454.20Min 1999(Trading Economics, 2018). The latest data showed a drop in Omani M1 from OMR 5039.60M in January 2018 to OMR 4963.80M in February 2018. 


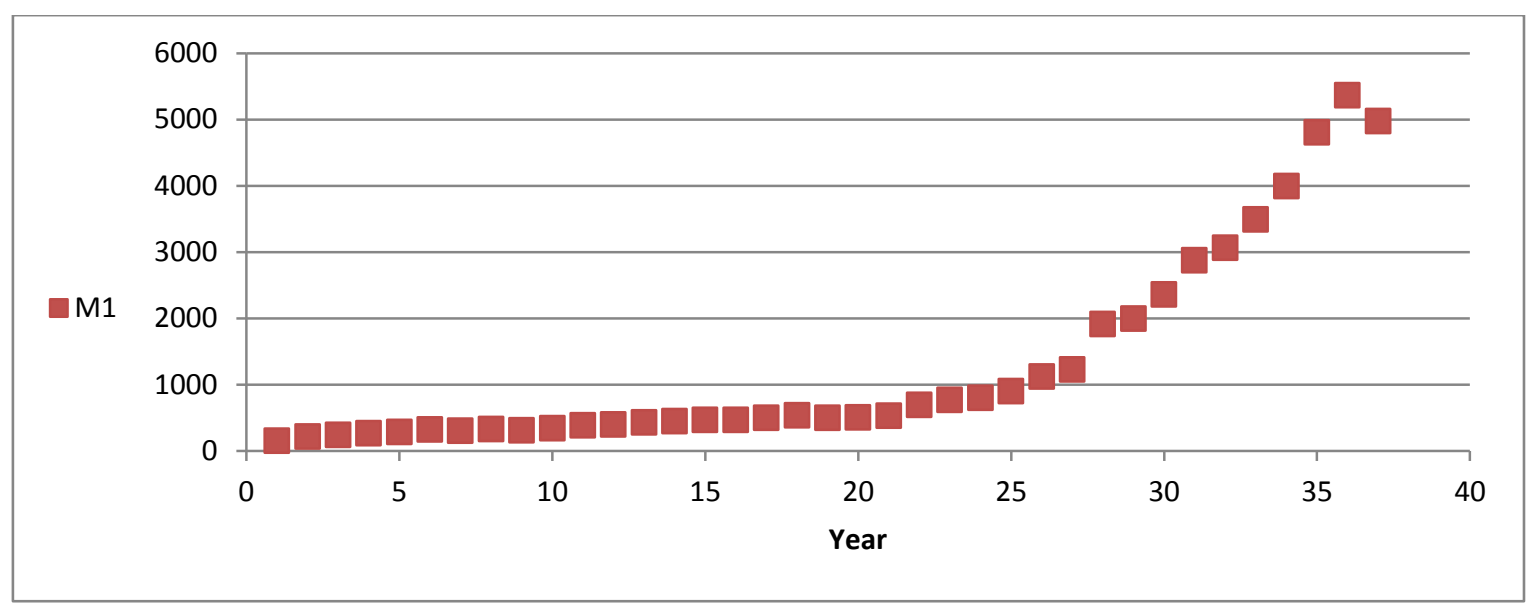

Fig. 1; Omani M1 data (1980-2016) -CBO

\subsection{Research Objectives and Hypotheses}

This study examines the association between oil price fluctuations and the narrow money supply (M1) and how these fluctuations impact Omani M1. Quantitative modelling is used to determine if oil price fluctuations (independent variable) have an impact on M1 (dependent variable) by measuring if $\pi$ is significantly equal to zero or not. The study will validate the following hypotheses to achieve its objectives, which can mathematically be written as:

$$
\begin{aligned}
& \text { H0: } \pi=0 \\
& \text { H1: } \pi \neq 0
\end{aligned}
$$

\section{Literature Review}

Scholars agree on a connection between crude oil prices and the supply of money. Rehman (2014) indicated that high energy prices would raise the cost of production, leading to the use of monetary policy to reduce cost-push inflation. He concluded that the cost side effects of oil prices would strengthen the cost side effects of monetary tightening, resulting in the dominance of cost side effects (Rehman, 2014, p.57). An empirical study by Pandey and Shettigar (2016)examining the relationship between crude oil prices, money supply, and inflation in India, concluded that crude oil prices driven by market demand have more impact on inflation than money supply. Omojolaibi's (2013) research on the Nigerian economy determined that oil shocks have significant positive impacts on economic output, but money shocks are the leading cause of GDP fluctuations. Hsieh (2008) used a simultaneousequation model to estimate the output elasticity concerning the real oil price in Korea that showed if the real oil price rises $10 \%$, real GDP will decrease by $0.42 \%$ (Hsieh, 2008, p.84), and real output is positively correlated with the money supply. Mpofu (2011) found that the money supply has a strong positive relationship with inflation, while the oil price has a negative one. Dlamini (2015) used a structural vector auto-regression (SVAR) model to examine the asymmetric effects of oil price shocks on monetary policy in South Africa, finding that a negative oil price shock has an insignificant effect on monetary policy tightening (Dlamini, 2015, p.57). Rahaman and Mustafa (2008) confirmed adverse effects on the U.S. stock market resulting from negative monetary policy and oil shocks. Azar (2013) declared that both oil and the US dollar react in the same manner to money supply changes. Cologni and Manera (2008) investigated oil prices, inflation and interest rates in a structural cointegrated VAR Model for the G-7 countries and found that unexpected oil price shocks impacted interest rates and the use of monetary policy to fight inflation. The same conclusion is found in research by Donayre and Wilmot (2016). Razmi et al.
(2015) found that the oil price remains an important factor in explaining price volatility, although this effect is weaker compared to the effect of the monetary transmission mechanism on prices. A similar result was found by Altintas and Yacouba (2018) in their study about Turkey; they discovered an asymmetric response of Turkish stock market prices to oil prices and money supply shocks. Similar findings derived by Caglayan and Uyar (2016) demonstrate that there is a linear relationship between oil prices and money supply. Kastele (2017) derived a vector error correction model (VECM) model from the VAR model to measure the relationship between the money supply and the commodity prices of oil, gold, and wheat. His study concluded that a long-term relationship of equilibrium exists between those variables and the amount of M2 money supply. Krichen (2006) concluded that monetary policy should be constructed to reduce oil prices, provide greater oil price stability, and provide overall price stability with an inflation rate not exceeding 2-3 percent a year.

Three is a limited number of studies investigated the relationship between the oil price and money supply in Oman. AlRiami (2007) concluded that domestic shocks, namely nominal money, and supply shocks, are the most critical factors driving non-oil output growth volatility in Oman. Around the same time, Ajmi (2007) identified a positive correlation between money supply, GDP, budget deficits, international reserves, and oil exports. More recent studies regarding oil price fluctuations and macroeconomic indicators are studies by Hakro and Omezzine (2016) and AlMawali et al. (2016).

\section{Data Description and Methodology}

\subsection{Data}

This study utilizes a quantitative approach to evaluate the effect of oil price oscillations on the Omani narrow money supply, using annual time series data from 1980 to 2016 to model the short and long-term impacts of oil price fluctuations on Omani M1. This study was utterly dependent on secondary data, assembled primarily from the Central Bank of Oman (CBO), World Bank, International Monetary Fund (IMF), and National Center of Statistics and Information (NCSI).

\subsection{Autoregressive Distributed Lag Approach}

The crude oil price fluctuations and their impacts on Omani M1 were investigated using an autoregressive distributed lag (ARDL) model. Chen, Kuo, and Chen (2010) stated that the ARDL approach uses a more dynamic model that is the norm. Others, including Nkoro and Uko (2016), Chittedi (2012), Oskenbayev, 
Yilmaz, and Chagirov (2011), and Hasan and Nasir (2008), have used this approach because of significant advantages compared to the previous approaches.

The ARDL method allows the integration of variables into different orders $\mathrm{I}(1)$ and $\mathrm{I}(0)$, and it allows for joint co-integration. Thus, if variable features are in an ambiguity state, the ARDL technique is the most suitable. Also, ARDL estimates are efficient and unbiased. Additionally, this model contains features such as (a) utility for small sample sizes; (b) support for the assessment of long as well as short-run connection approaches, and (c) usefulness regardless if variables are non-stationary or stationary. Several scholarly studies, including those by Ahmad (2019a), Ahmad(2019b), Ahmed(2018b), and Hasan and Nasir (2008), show that compared to VAR models, ARDL models can accommodate a significant amount of variables. The advantages of ARDL were supported by Alqattan and Alhayky (2016) stating that Pesaran, Shin, and Smith (2001) developed a new ARDL approach as an alternate co-integration technique, named" the error correction version, "that supports testing the presence of long-run relationships among variables of interest.

General ARDL equation:

$$
\begin{gathered}
d(Y t)=c+\lambda Y \mathrm{t}-1+\beta X \mathrm{t}-1+\sum_{i=1}^{m} a 1, i * d(Y t-i)+\sum_{i=0}^{k} a 2, i * d(X t-1)+\varepsilon \mathrm{t} \\
c+\lambda Y \mathrm{t}-1+\beta X \mathrm{t}-1 \text { : Long-run association } \\
\sum_{i=1}^{m} a 1, i * d(Y t-i)+\sum_{i=0}^{k} a 2, i * d(X t-1)+\varepsilon \mathrm{t}: \text { Short-run association }
\end{gathered}
$$

\subsection{Empirical Estimation and Findings}

VAR Lag Order Selection Criteria was conducted to define the number of selected lags for both variables of interest to ensure nonresidual autocorrelation, and unit root tests were run to ensure none of the variables were $\mathrm{I}(2)$. The results showed that M1 is $\mathrm{I}(1)$, whereas OIL-PRICE is I(0). Augmented Dickey-Fuller (ADF) tests, run to the levels as well as the first differences of the data series, failed to accept the null hypothesis of non-stationarity for both. Table 1 and Table 2 show that the variables under investigation have no unit root because their critical test values are less than the ADF t-Statistic. M1 is integrated of order one I(1)

\begin{tabular}{|c|c|c|c|}
\hline $\begin{array}{l}\text { Null Hypothesis: D } \\
\text { Exogenous: Consta } \\
\text { Lag Length: } 0 \text { (Aut }\end{array}$ & $\begin{array}{l}\text { M1) has a u } \\
\text { Linear } \mathrm{Tr} \\
\text { matic - bas }\end{array}$ & SIC, maxla & \\
\hline & & t-Statistic & Prob.* \\
\hline \multicolumn{2}{|c|}{$\begin{array}{l}\text { Augmented Dickey-Fuller test } \\
\text { statistic }\end{array}$} & -4.110139 & 0.0138 \\
\hline \multirow{3}{*}{$\begin{array}{l}\text { Test } \quad \text { critical } \\
\text { values: }\end{array}$} & $1 \%$ level & -4.243644 & \\
\hline & $5 \%$ level & -3.544284 & \\
\hline & $10 \%$ level & -3.204699 & \\
\hline
\end{tabular}
while oil price (OIL-PRICE) is integrated of order zero $\mathrm{I}(0)$.

Table 1: Results of Unit Roots Tests at First Difference

The above Table shows that using their absolute values, the critical test value at the 5\% level (3.544284) is less than the ADF t-
Statistic of 4.110139. Therefore, the Null-Hypothesis that D(M1) has a unit root is rejected, and instead, we accept the Alternative Hypothesis that D(M1) is stationary at the first difference and is

\begin{tabular}{|c|c|c|c|}
\hline \multicolumn{4}{|c|}{$\begin{array}{l}\text { Null Hypothesis: D(OIL-PRICE) has a unit root } \\
\text { Exogenous: Constant, Linear Trend } \\
\text { Lag Length: } 0 \text { (Automatic - based on SIC, maxlag=0) }\end{array}$} \\
\hline & & t-Statistic & Prob.* \\
\hline \multicolumn{2}{|c|}{$\begin{array}{lll}\text { Augmented } & \text { Dickey-Fuller } & \text { test } \\
\text { statistic } & & \end{array}$} & -9.788208 & 0.0000 \\
\hline \multirow{3}{*}{$\begin{array}{l}\text { Test critical } \\
\text { values: }\end{array}$} & $1 \%$ level & -4.243644 & \\
\hline & $5 \%$ level & -3.544284 & \\
\hline & $10 \%$ level & -3.204699 & \\
\hline
\end{tabular}
integrated of order one $\mathrm{I}(1)$.

Table 2: Results of Unit Roots Tests at Levels

Table 2 displays that the Critical Test value at the 5\% level (3.544284) is lower than the ADF t-Statistic of 9.788208 . Therefore, we reject the Null-Hypothesis and alternatively accept the Alternative Hypothesis that D(O-PRICE) has no unit root and is $\mathrm{I}(0)$ after running the unit root tests and assuring that no one variable is $\mathrm{I}(2)$. The estimation was conducted using the ARDL cointegration technique before empirical analyses of long-run relations and short-run dynamic interactions amongst the variables to avoid any spurious regression. Table 3 shows the result of this

\begin{tabular}{|c|c|c|c|}
\hline \multicolumn{4}{|c|}{$\begin{array}{l}\text { Dependent Variable: M1 } \\
\text { Method: ARDL }\end{array}$} \\
\hline Variable & \multicolumn{2}{|c|}{ Coefficient } & Prob.* \\
\hline M1(-1) & \multicolumn{2}{|c|}{1.041346} & 0.0020 \\
\hline M1(-2) & \multicolumn{2}{|c|}{0.637322} & 0.1224 \\
\hline M1(-3) & \multicolumn{2}{|c|}{0.260817} & 0.5295 \\
\hline M1(-4) & \multicolumn{2}{|c|}{-1.355704} & 0.0033 \\
\hline OPRICE & \multicolumn{2}{|c|}{0.041173} & 0.0494 \\
\hline OPRICE(-1) & \multicolumn{2}{|c|}{0.032979} & 0.0797 \\
\hline OPRICE(-2) & \multicolumn{2}{|c|}{0.061471} & 0.0075 \\
\hline OPRICE(-3) & \multicolumn{2}{|c|}{0.122960} & 0.0000 \\
\hline OPRICE(-4) & \multicolumn{2}{|c|}{0.079435} & 0.0017 \\
\hline $\bar{C}$ & \multicolumn{2}{|c|}{179.4592} & 0.0019 \\
\hline R-squared & 0.995527 & Mean dependent var & $3.56 \mathrm{E}+09$ \\
\hline Adjusted R-squared & 0.992971 & S.D. dependent var & $1.60 \mathrm{E}+09$ \\
\hline S.E. of regression & $1.35 \mathrm{E}+08$ & Akaike info criterion & 40.55870 \\
\hline
\end{tabular}
estimation.

Table 3: Estimation using ARDL model 


\begin{tabular}{|l|l|l|l|}
\hline Sum squared resid & $2.53 \mathrm{E}+17$ & Schwarz criterion & 41.00303 \\
\hline Log-likelihood & -457.4251 & Hannan-Quinn criter & 40.67045 \\
\hline F-statistic & 389.4615 & Durbin-Watson stat & $\mathbf{1 . 9 0 7 9 5 5}$ \\
\hline Prob(F-statistic) & 0.000000 & & \\
\hline
\end{tabular}

The R-squared (0.995527) is lower than the value of the Durbin-Watson statistic (1.907955), demonstrating that there is no spurious regression. The estimation equation and its substituted coefficients are shown below:

\section{Estimation Equation}

$\mathrm{M} 1=\mathrm{C}(1) * \mathrm{M} 1(-1)+\mathrm{C}(2) * \mathrm{M} 1(-2)+\mathrm{C}(3) * \mathrm{M} 1(-3)+\mathrm{C}(4) * \mathrm{M} 1(-4)$ $+\mathrm{C}(5) * \mathrm{OPRICE}+\mathrm{C}(6) * \mathrm{OPRICE}(-1)+\mathrm{C}(7) * \mathrm{OPRICE}(-2)+$ $\mathrm{C}(8) *$ OPRICE$(-3)+\mathrm{C}(9) *$ OPRICE$(-4)+\mathrm{C}(10)$

\section{Substituted Coefficients}

$\mathrm{M} 1=1.04134578678 * \mathrm{M} 1(-1)+0.637322387047 * \mathrm{M} 1(-2)+$ $0.260817146744 * \mathrm{M} 1(-3)-1.3557044762 * \mathrm{M} 1(-4)+$ $0.041173477884 *$ OPRICE $+0.0329789187589 *$ OPRICE $(-1)+$ $0.0614711516019 *$ OPRICE $(-2)+0.122959824275 *$ OPRICE $(-3)+$ $0.0794352953335 *$ OPRICE $(-4)+179.459210899$

The mode of co-integration not only preserves long-term information, but also avoids false regression specification. After confirming that all variables are integrated of order 0 or order 1 , or are of different orders, the next step is to assess the connection between M1and oil price fluctuations. The following table illustrates the nature of this connection between the two variables.

Table 4: ARDL Bounds Test

\begin{tabular}{|l|l|l|l|l|}
\hline F-Bounds Test: Null Hypothesis: No levels Relationship \\
\hline Test Statistic & Value & Signif & $\mathbf{1}(\mathbf{0})$ & $\mathbf{1}(\mathbf{1})$ \\
\hline Asymptotic: $\mathrm{n}=1000$ & 9.495979 & $10 \%$ & 3.02 & 3.51 \\
\hline F-statistic & 1 & $5 \%$ & 3.62 & 4.16 \\
\hline K & & $2.5 \%$ & 4.18 & 4.79 \\
\hline & & $1 \%$ & 4.94 & 5.58 \\
\hline & & Actual Sample Size & 33 \\
\hline Finite Sample: $\mathrm{n}=35$ & $10 \%$ & 3.223 & 3.757 \\
\hline & $5 \%$ & 3.957 & 4.53 \\
\hline & $1 \%$ & 5.763 & 6.48 \\
\hline & & \multicolumn{4}{|l}{} \\
\hline Finite Sample: $\mathrm{n}=30$ & $10 \%$ & 3.303 & 3.797 \\
\hline & $5 \%$ & 4.09 & 4.663 \\
\hline & $1 \%$ & 6.027 & 6.76 \\
\hline
\end{tabular}

Table 4 shows the long-run association among the two variables is present. If the F-statistic (9.49) is higher than the I(1) Bound at $10 \%$ (3.51), 5\% (4.16), 2.5\% (4.79), and 1\% (5.58),the study is in a position to reject the null hypothesis and consider the alternative hypothesis that a long-run linkage between the variables of interest -oil prices and M1- exists.

The final stage involves conducting the error correction representation to measure the adjustment speed to rebuild stability in the dynamic model and check whether the equilibrium, in the long run, can be touched. The following table is used for this purpose.

Table 5: Error Correction Representation for the selected ARDL

\section{ECM Regression}

Case 2: Restricted Constant and No Trend

\begin{tabular}{|l|l|l|}
\hline Variable & Coefficient & Prob. \\
\hline D(M1(-1)) & 0.457565 & 0.0626 \\
\hline D(M1(-2)) & 1.094887 & 0.0003 \\
\hline
\end{tabular}

\begin{tabular}{|l|l|l|}
\hline $\mathrm{D}(\mathrm{M} 1(-3))$ & 1.355704 & 0.0004 \\
\hline $\mathrm{D}($ OPRICE) & 0.041173 & 0.0354 \\
\hline $\mathrm{D}($ OPRICE $(-1))$ & -0.263866 & 0.0000 \\
\hline $\mathrm{D}($ OPRICE $(-2))$ & -0.202395 & 0.0000 \\
\hline $\mathrm{D}($ OPRICE $(-3))$ & -0.079435 & 0.0010 \\
\hline CointEq(-1) & $\mathbf{- 0 . 4 1 6 2 1 9}$ & $\mathbf{0 . 0 0 0 0}$ \\
\hline
\end{tabular}

\section{Co-integrating Equation}

$\mathrm{D}(\mathrm{M} 1)=179.459210898989-0.416219155626 * \mathrm{M} 1(-1)+$ $0.338018667853 *$ OPRICE(-1) + 0.457564942410*D(M1(-1)) + $1.094887329457 * \mathrm{D}(\mathrm{M} 1(-2))+1.355704476201 * \mathrm{D}(\mathrm{M} 1(-3))+$ $0.041173477884 * \mathrm{D}(\mathrm{OPRICE})-0.263866271211 * \mathrm{D}(\mathrm{OPRICE}(-1))-$ $0.202395119609 *(\mathrm{M} 1-(0.81211704 *$ OPRICE $(-1)+$ 431.16518899 ) $-0.079435295334 * \mathrm{D}(\mathrm{OPRICE}(-3)))$

In Table 5 and the co-integrating equation, the ECR for the OPRICE was represented by $(\mathrm{CointEq}(-1)-(\lambda))$. The CointEq(-1), determining the adjustment speed to rebuild stability in the dynamic model, is negative (-0.416219) and statistically significant $(0.0000)$ at the $1 \%$ level, evidencing that long-run equilibrium can be touched. The coefficient of CointEq(-1) equaling -0.416219 for the short run model signifies that deviation from the long-term variation is corrected by $41.6 \%$ every year.

As with previous research, the analytical results in this study confirm a connection between the variables under investigation narrow money supply (M1)is positively related to oil prices. This finding is important because oil plays such a significant role in the Omani economy. However, more research is needed to understand better all the factors affecting economic behaviour in Oman, but this study should alarm policymakers on the significant challenge of diversifying the Omani economy.

\section{Conclusion}

This study was conducted to evaluate the money supply impact of oil price fluctuations in the Sultanate of Oman. The employment of the autoregressive distributed lag (ARDL) technique provides evidence that oil price changes are positively associated with the Omani narrow money supply (M1) in the long-term, as all statistics of association significance confirm that a long-run correlation between the variables takes place. The use of ARDL proved very useful to study the long-run relations and short-run dynamic interactions among the variables of interest.

The Omani oil market has seen its share of price instability, which has been recognized by the Omani policymakers and resulted in the realization that economic diversification is needed (Al Omari, 2019, p.312). After all, the Omani economy is still depending entirely on oil revenues (Al-Mawali, Hasim, and AlBusaidi, 2016; Alodayni, 2016; Ahmad, 2019b). The impact of economic diversification and its impact on the money supply need more exploration and research. Furthermore, this study recommends using more extensive models when conducting future research on the same topic and intensely studying the impacts of oil price oscillations on several macroeconomic indicators in the Sultanate 


\section{Data Availability}

This study was entirely dependent on secondary data, accumulated primarily from the Central Bank of Oman (CBO), World Bank, International Monetary Fund (IMF), and National Center of Statistics and Information (NCSI) of Oman, from 1980-2016.

\section{Conflicts of Interest}

We declare that there is no conflict of interest regarding the publication of this paper.

\section{Funding Statement}

This research is self-funded by the researchers.

\section{References}

[1] Ahmed, Abubakar El-Sidig (2018a). Impact of Crude Oil Price Fluctuations on Governmental Expenditures in the Sultanate of Oman (1990-2017), GCNU Journal, 11(44):178-192

[2] Ahmed, Abubakar El-Sidig (2018b). Relationship between Crude Oil Price Fluctuations and Inflation in Oman, GCNU Journal, 12 (46):1-15.

[3] Ahmed, Abubakar El-Sidig (2019a). The Impact of Crude Oil Prices changes on Money Supply (M2) in Oman (1990-2016), Global Scientific Journals, 7 (3):418-435.

[4] Ahmed, Abubakar El-Sidig (2019b). Impact of Crude Oil Price Fluctuations on Oman's Employment Rate (19902016), Global Scientific Journals, 7 (3):138-156.

[5] Ajmy Hilal Jamil (2007). Money Supply in Oman, Journal of Economic and Administrative Sciences, 23(2):14-43.

[6] Al Omari, Bilal Khlaf (2019). Tourism Economics in Oman: A Statistical Study for the Period 2000-2017, Global Scientific Journals (7) 3: 301-312.

[7] Al-Mawali, Nassar, Haslifah M.Hasim\&Khalil AlBusaidi, (2016).Modelling the Impact of the Oil Sector on the Economy of Sultanate of Oman, International Journal of Energy Economics and Policy, 6(1), 120-127.

[8] Alqattan, Abdulrahman Adnan, \& and Ahmed Alhayky (2016). Impact of Oil Prices on Stock Markets: Evidence from Gulf Cooperation Council (GCC) Financial Markets, Amity Journal of Finance: (1)1:1-8-8.

[9] AlRiyami Mazin Hamed (2007). Sources of Macroeconomic Fluctuations in a small, Developing, Oil Exporting Economy: The Case of The Sultanate of Oman. American University in Partial..D.Ph.D.thesis.

[10] Altintas, Halil and KassouriYacouba, (2018). Asymmetric Responses of Stock Prices to Money Supply and Oil Prices Shocks in Turkey: New Evidence from a Nonlinear ARDL Approach, International Journal of Economics and Financial Issues, 8(4): 45.

[11] Chen, Sheng-Tung; Hsiao-IKuo and Chi-Chung Chen (2010).Modelling the Relationship between Oil Price and Global Food Prices, Applied Energy, 87(8): 2517-2525.

[12] Chittedi, Krishna Reddy (2012). Do Oil Prices Matter for Indian Stock Markets? An Empirical Analysis, Journal of Applied Economics and Business Research, 2(1): 2-10.
[13] Cologni, Allesandro and Matteo Manera, (2008). Oil Prices, Inflation and Interest Rates in a Structural Cointegrated VAR Model for the G-7 Countries, Energy Economics, 30(3): 856-888.

[14] Dlamini, Lenhle Precious (2015). Master's Thesis: Monetary Policy and Asymmetric Effects of Oil Shocks in South Africa, School of Accounting, Economics and Finance, University of KwaZulu Natal, https://researchspace.ukzn.ac.za/handle/10413/14144.

[15] Donayre, Luiggi and Neil Wilmot (2016). The Asymmetric Effects of Oil Price Shocks on the Canadian Economy, International Journal of Energy Economics and Policy, 6(2): 167-182.

[16] Ebru Caglayanand Sinem and Guler Kangalli Uyar (2016). Determining the Functional Form of Relationships Between Oil Prices and Macroeconomic Variables: The Case of Mexico, Indonesia, South Korea, Turkey Countries, International Journal of Economics and Financial Issues, 6(3): 880-891.

[17] Hakro, Ahmed and Abdallah Omezzine (2016). Oil Prices and Macroeconomic Dynamics of the Oman Economy, the Journal of Developing Areas, 50(1): 1-27.

[18] Hasan, Arshad and Zafar Mueen Nasir (2008). Macroeconomic Factors and Equity Prices: An Empirical Investigation by Using ARDL Approach, Pakistan Development Review, 47(4): 501-515.

[19] Hsieh, Wen-Jen (2008). Effects of Oil Price Shocks and Macroeconomic Conditions on Output Fluctuations for Korea, Journal of International and Global Economic Studies, 1(2): 84-91.

[20] Kasteler, Aaron (2017). Quantitative Easing: Money Supply and the Commodity Prices of Oil, Gold, and Wheat, Thesis, Utah State University.

[21] Krichene, Noureddine (2006). World Crude Oil Markets: Monetary Policy and the Recent Oil Shock, No. 6-62, International Monetary Fund. No. 6-62,

[22] Mpofu, Raphael Tabani (2011). Money supply, interest rate, exchange rate and oil price influence on inflation in South Africa, Journal of Corporate Ownership and Control, 8(3): 594-605.

[23] NkoroEmeka and UkoAham Kelvin Nkoro, E. \& A. K. Uko (2016). Autoregressive Distributed Lag (ARDL) cointegration technique: application and interpretation, Journal of Statistical and Econometric Methods, 5(4): 6391.

[24] Omojolaibi, Joseph (2013). Does Volatility in Crude Oil Price Precipitate Macroeconomic Performance in Nigeria? International Journal of Energy Economics and Policy, 3(2): 143-152.

[25] Oskenbayev, Yessengali, Mesut Yilmaz and Dauren Chagirov (2011). The Impact of Macroeconomic Indicators on Stock Exchange Performance in Kazakhstan, African Journal of Business Management, 5(7): 2985-2991.

[26] Pandey, Amrendra and Jagdish Shettigar (2016). A Relationship between Crude Oil Prices, Money Supply, and Inflation in India, International Journal of Advanced Research in Management and Social Sciences, 5(7): 2031.

[27] Rahman, M. and Mustafa Muhammed (2008). Influences of money supply and oil price on the US stock market. North American Journal of Finance and Banking Research, 2(2): 1-13. 
[28] Ramzi, Fatemeh, Azali Mohamed, Lee Chin and Muzafar Habibullah,(2015). The Role of Monetary Policy in Macroeconomic Volatility of Association of Southeast Asian Nations-4 Countries against Oil Price Shock over Time, International Journal of Energy Economics and Policy, 5(3): 731-737.
[29] Rehman, Atiq-ur (2014). Relationship Between Energy Prices, Monetary Policy and Inflation; A Case Study of South Asian Economies. Journal of Central Banking Theory and Practice,3(1):43-58

[30] SamihAzar (2013). Oil prices, US inflation, US money supply and the US dollar, OPEC Energy Review, 37(4). 